\title{
Effects of 2010 Hurricane Earl amidst geologic evidence for greater overwash at Anegada, British Virgin Islands
}

\author{
B. F. Atwater ${ }^{1}$, Z. Fuentes ${ }^{2}$, R. B. Halley ${ }^{*}, * *$, U. S. Ten Brink ${ }^{3}$, and M. P. Tuttle ${ }^{4}$ \\ ${ }^{1}$ USGS, Seattle, WA, USA \\ ${ }^{2}$ University of Puerto Rico, Mayagüez, Puerto Rico \\ ${ }^{3}$ USGS, Woods Hole, MA, USA \\ ${ }^{4} \mathrm{M}$. Tuttle \& Associates, Georgetown, ME, USA \\ * formerly at: USGS, 600 4th St South, St. Petersburg, FL 33701, USA \\ ${ }^{* * *}$ retired \\ Correspondence to: B. F. Atwater (atwater@u.washington.edu)
}

Received: 2 August 2013 - Revised: 18 December 2013 - Accepted: 20 January 2014 - Published: 7 March 2014

\begin{abstract}
A post-hurricane survey of a Caribbean island affords comparisons with geologic evidence for greater overwash at the same place. This comparison, though of limited application to other places, helps calibrate coastal geology for assessment of earthquake and tsunami potential along the Antilles Subduction Zone.

The surveyed island, Anegada, is $120 \mathrm{~km}$ south of the Puerto Rico Trench and is near the paths of hurricanes Donna (1960) and Earl (2010), which were at or near category 4 when at closest approach. The survey focused on Earl's geologic effects, related them to the surge from Hurricane Donna, and compared them further with erosional and depositional signs of southward overwash from the Atlantic Ocean that dates to 1200-1450 AD and to 1650-1800 AD. The main finding is that the geologic effects of these earlier events dwarf those of the recent hurricanes.

Hurricane Earl's geologic effects at Anegada, observed mainly in 2011, were limited to wrack deposition along many of the island's shores and salt ponds, accretion of small washover (spillover) fans on the south shore, and the suspension and deposition of microbial material from interior salt ponds. Earl's most widespread deposit at Anegada, the microbial detritus, was abundantly juxtaposed with evidence for catastrophic overwash in prior centuries. The microbial detritus formed an extensive coating up to $2 \mathrm{~cm}$ thick that extended into breaches in beach-ridge plains of the island's north shore, onto playas that are underlain by a sandand-shell sheet that extends as much as $1.5 \mathrm{~km}$ southward from the north shore, and among southward-strewn lime-
\end{abstract}

stone boulders pendant to outcrops as much as $1 \mathrm{~km}$ inland. Earl's spillover fans also contrast with a sand-and-shell sheet, which was dated previously to $1650-1800$, by being limited to the island's south shore and by extending inland a few tens of meters at most.

These findings complement those reported in this issue by Michaela Spiske and Robert Halley (Spiske and Halley, 2014), who studied a coral-rubble ridge that lines part of Anegada's north shore. Spiske and Halley attribute the ridge to storms that were larger than Earl. But they contrast the ridge with coral boulders that were scattered hundreds of meters inland by overwash in 1200-1450.

\section{Introduction}

This report describes geologic effects of a recent hurricane at Anegada, a low-lying island in the northeast Caribbean (Fig. S1). The work was spurred by two questions: whether the Antilles Subduction Zone produces great earthquakes, of magnitude 8 or 9 , and the tsunamis that typically accompany such earthquakes; and how to distinguish between storms and tsunamis by means of their geologic records.

Written history spanning the last few centuries provides ambiguous evidence for great earthquakes along the Antilles Subduction Zone in 1787 and 1843. The accounts from 1787, in Puerto Rico, though cited as evidence for a thrust earthquake offshore (McCann, 1985), mention no tsunami and can be explained by faulting onshore (ten Brink et al., 2011). 
An earthquake farther east in 1843 has been attributed to interplate thrusting, but the accounts of this earthquake also give no evidence for the expected tsunami (Feuillet et al., 2011; Beauducel and Feuillet, 2012).

Geology from recent millenniums can forewarn of unusually large earthquakes and tsunamis. The approach yielded such forewarnings along the Pacific coast of North America (Atwater et al., 2005) and, belatedly, on shores that were overrun by the Indian Ocean tsunami of 2004 (Jankaew et al., 2008; Monecke et al., 2008; Meltzner et al., 2010; Rajendran et al., 2013). The added challenge in the Caribbean is to distinguish the geologic records of tsunamis from those of storms (Sect. 2.2).

We focused on Anegada because of its evidence, reviewed below in Sect. 3, for catastrophic overwash in 1200-1450 AD and $1650-1800 \mathrm{AD}$. Some of this evidence was previously compared with eyewitness accounts of the island's largest 20th-century storm, 1960 Hurricane Donna (Atwater et al., 2012b). Geologic effects of 2010 Hurricane Earl, described in this paper, afford further calibration, as does a related study by Spiske and Halley (2014), who in 2013 examined a coral-rubble ridge along Anegada's north shore.

We spent one week at Anegada in February 2011, six months after Hurricane Earl, to identify storm-surge limits and examine geologic effects. We made comparisons with Hurricane Donna and with erosional and depositional features from overwash in 1650-1800 and earlier. Coral samples collected incidentally during the survey yielded an age for the island's Pleistocene deposits and the first ages for the overwash event of 1200-1450.

This report provides a virtual field trip to the 2011 findings. The report's photographs and drawings together cover most of 30 pages and are placed in the Supplement. They are grouped into six subjects: setting (Fig. S1), dating of Pleistocene deposits (Fig. S2), storm-surge limits (Fig. S3), spillover landforms (Fig. S4), spillover stratigraphy (Fig. S5), and head-to-head comparisons between geologic effects of Hurricane Earl and geologic evidence for prehistoric overwash (Fig. S6).

\section{Motivations}

\subsection{Assessing earthquake and tsunami hazards along the eastern Puerto Rico Trench}

Earthquake and tsunami hazards along the eastern Puerto Rico Trench are difficult to estimate because the region's written history is geologically short, its interplate coupling uncertain and (or) spatially variable, and its paleoseismological evidence limited (ten Brink et al., 1999; Mann, 2005; Mercado-Irizarry and Liu, 2006; Harbitz et al., 2012).

The Puerto Rico Trench marks the northwestern part of the Antilles Subduction Zone. The interplate motion, which trends nearly parallel to the Puerto Rico Trench, averages two meters per century (López et al., 2006). At this rate a giant earthquake, with $20 \mathrm{~m}$ of slip on average, would represent $1000 \mathrm{yr}$ of subduction - twice the duration of the region's written history.

Hypothetically, this slow subduction can generate interplate-thrust earthquakes and associated tsunamis along the Puerto Rico Trench. Interplate thrust earthquakes occurred to the west in 1943 and 1958, and the 1943 earthquake was accompanied by a devastating tsunami in the Dominican Republic (Dolan and Wald, 1997, 1998). Farther east and southeast, by contrast, written and instrumental records have yet to show the joint occurrence of a great thrust earthquake and a tsunami, as noted above, and modeling of geodetic evidence suggests that the plate boundary is too weakly coupled to generate a giant earthquake north of Puerto Rico and the Virgin Islands (ten Brink and López-Venegas, 2012). Nonetheless, the Antilles plate boundary is large enough to produce an earthquake of magnitude 9 (McCaffrey, 2008), and concern about the possibility of such an earthquake extends to the US Atlantic Seaboard, where a tsunami from the Puerto Rico Trench could cause flooding (Geist and Parsons, 2009).

Other potential tsunami sources also adjoin the Puerto Rico Trench. To the north the trench is flanked by normal faults on the outer rise of unknown earthquake and tsunami potential (ten Brink et al., 2004), while to the south a submarine slide probably contributed to a 1918 tsunami in western Puerto Rico (López-Venegas, 2008).

The Lisbon tsunami of 1755 raised and (or) lowered the sea at several Caribbean islands (Barkan et al., 2009). Its farfield waves are among the potential causes of the overwash at Anegada in 1650-1800 (Atwater et al., 2012b).

\subsection{Distinguishing between geologic records of storms and geologic records of tsunamis}

Many regions present the challenge of how to distinguish between tsunamis and storms in geologic records (Morton et al., 2007). Examples include Iberia (Kortekaas and Dawson, 2007; Lario et al., 2010), Japan (Nanayama et al., 2000; Sawai et al., 2008), Australia (Switzer and Jones, 2008), New Zealand (Goff et al., 2004), North America (Tuttle et al., 2004), and Oman (Fritz et al., 2010).

In the northeast Caribbean (Fig. S1-1a, b), geologic evidence for tropical cyclones has been reported from sites on and near Puerto Rico. Hurricane Hugo, in 1989, damaged coral reefs and deposited sandy overwash fans as its right front quadrant raked Puerto Rico (Bush, 1991; Rodríguez et al., 1994). A notable Hugo fan deposit extended inland about $100 \mathrm{~m}$ across a coastal road into a mangrove swamp. Earlier hurricanes, mainly of pre-Columbus age, have been inferred from sand beds beneath the floors of a salt pond at Isla de Culebrita (Donnelly, 2005) and a lagoon at Vieques (Donnelly and Woodruff, 2007; Woodruff et al., 2008a, b; Mann et al., 2009) (locations, Fig. S1-1b). These 
latter findings extend, into the tsunami-prone Caribbean, the "paleotempestology" of marshes and ponds on the US Atlantic and Gulf coasts (reviewed by Hippensteel, 2010).

Several additional studies have described the geologic effects of hurricanes in the Caribbean and vicinity. In south Florida in 1960, Hurricane Donna damaged coral reefs and mantled onshore areas with lime mud (Ball et al., 1967). In the Lesser Antilles, other modern hurricanes built bouldery deposits on shores directly exposed to large waves (Scheffers and Scheffers, 2006; Spiske and Jaffe, 2009).

Distinguishing between tsunami and storm by means of onshore boulders has been a matter of controversy in the Caribbean (Scheffers et al., 2005; Morton et al., 2006, 2008; Spiske et al., 2008). The challenge has been taken up on other coasts as well (examples: Switzer and Burston, 2010; Richmond et al., 2011; Shah-hosseini et al., 2011; Cox et al., 2012; Hoffman et al., 2014). These efforts spurred the study of Anegada's coral-rubble ridge that is reported elsewhere in this issue (Spiske and Halley, 2014).

Either a tsunami or a storm may breach coastal berms and build fans behind them. The pairing of a tsunami's breaches and fans was first noted as an effect of the Pacific Ocean tsunami associated with the giant Chilean earthquake of 22 May 1960. In northeast Japan, inflow and outflow by the 1960 tsunami breached roads and levees (Kon'no et al., 1961). In Chile itself, inflow reamed out a breach in a beach ridge through which two prior tsunamis had also run (Atwater et al., 2013). The 2004 Indian Ocean tsunami cut through beach ridges in Indonesia, Thailand, and Sri Lanka (Choowong et al., 2007; Goff et al., 2007, p. 11, 29, 31; Fagherazzi and Du, 2008), and the 2011 tsunami in northeast Japan breached sand spits there (Tanaka et al., 2012). However, modern storms have also breached of beach ridges and opened inlets, as illustrated on the US Atlantic and Gulf coasts (Morton and Sallenger, 2003; Buynevich and Donnelly, 2006; Otvos and Carter, 2008).

\section{Setting}

Anegada, $120 \mathrm{~km}$ south of the Puerto Rico Trench, shows promise as a geologic guide to tsunamis, unusually large storms, or both. The island has provided abundant geologic evidence for overwash from the north that overtopped beach ridges at least $3 \mathrm{~m}$ high, dates to the interval 1650-1800, and has been ascribed to a tsunami or, perhaps, a storm (Atwater et al., 2012b; Buckley et al., 2012; Pilarczyk and Reinhardt, 2012; Reinhardt et al., 2012; Watt et al., 2012). The island has also provided evidence for overwash that dates to 1200 1450 and which may represent a tsunami from outer-rise or interplate-thrust faulting along the eastern Puerto Rico Trench (Atwater et al., 2012a; Wei et al., 2012; Weil Accardo et al., 2012).

These findings rest in part on comparisons between the observed geology and the observed and modeled effects of hur- ricanes. Observations by eyewitnesses, interviewed in 2008, provide the basis for storm-surge heights estimated for Hurricane Donna (Atwater et al., 2012b, Fig. ESMF-1). Hurricane modeling suggests that storm effects on the island's north side are limited by a fringing reef on which storm waves break and by deep water to the reef's north that limits the depth-averaged effect of wind-driven currents (Caribbean Disaster Mitigation Project, 2002; Buckley et al., 2012; Wei et al., 2012). Anegada's geologic evidence for catastrophic overwash in 1200-1450 and 1650-1800 far exceeds the geologic effects of Hurricanes Donna and Earl, as illustrated below for Hurricane Earl in Sect. 4.4.

\subsection{Geologic overview}

Anegada comprises limestone uplands, beach ridges, and salt ponds, all flanked to the north and east by a fringing reef (Fig. S1-1d, S1-2). The island reaches maximum elevations of 7-8 $\mathrm{m}$ a.s.l. northwest of The Settlement. The surficial materials in this relatively high area, and in most other parts of the island's eastern half, consist of Pleistocene reefal and lagoonal carbonates that have been cemented into limestone (or caliche). Sandy beach ridges of Holocene age fringe most of the island and corrugate much of the island's western half.

Scars of breaches interrupt many of the beach ridges near the island's northwestern shore. Two generations of breaches are geomorphically superposed north of Flamingo Pond. The earlier formed when the shoreline was close to position 1 in Fig. S1-2b, and the later formed when the beach was near position 2. Breaches farther east, mapped north of Red Pond and Bumber Well Pond in 2008 and 2009, were initially ascribed to overwash in 1650-1800 (Atwater et al., 2012b). However, field work in 2011-2013 revealed that heads of brain coral (Diploria strigosa) were washed hundreds of meters inland in 1200-1450, as summarized in meeting abstracts by Weil Accardo et al. (2012) and Atwater et al. (2012a), and illustrated in this issue by Spiske and Halley (2014). This overwash may have cut many of the breaches previously ascribed to the overwash of 1650-1800, which then reused them.

Beach ridges and limestone together confine the island's salt ponds. These coalesce when adjoining playas flood during hurricane season, as illustrated by the post-Earl photo in Fig. S3-4a and by water-level graphs of Jarecki and Walkey (2006). The salt ponds become separate and fall below mean sea level during dry months (Fig. S6-1b).

\subsection{Pleistocene deposits}

A Pleistocene deposit exposed at Anegada has been dated to the last interglaciation by means of uranium-series analysis of a well-preserved coral sample from deposits a few meters above modern sea level (Fig. S2-1).

We collected this coral sample from stratified bioclastic deposits exposed in the wall of a sand pit. The pit had been 
dug through surficial caliche. The ground surface beside the pit is probably in the range of $4-8 \mathrm{~m}$ a.s.l., according to topography from the Shuttle Radar Topographic Mission. In the pit wall, $2 \mathrm{~m}$ of caliche overlie mostly unconsolidated carbonate deposits that include imbricated slabs of beach rock (Fig. S2-1b, d).

The dated sample, of the finger coral Porites furcata, was collected about $3 \mathrm{~m}$ below the top of the pit wall and a few tens of centimeters below the slabs. Some of the pieces retain pink encrustations of the reef-dwelling protozoan $\mathrm{Ho}$ motrema rubra (Fig. S2-1e).

The uranium-series age was measured by William Thompson of Woods Hole Oceanographic Institution. The age incorporates half lives of Cheng et al. (2000) and passed the closed-system test of Thompson et al. (2011) (Fig. S2-1f).

Dated corals elsewhere show that global sea level exceeded present levels for much of the time between 115000 and $125000 \mathrm{yr}$ ago, and that it peaked about $124000 \mathrm{yr}$ ago in the range of 6-10 $\mathrm{m}$ above present levels (Kopp et al., 2009). Examples near Anegada have been reported recently from Florida (Muhs et al., 2011) and St. Croix (Toscano et al., 2012). If the dated finger coral at Anegada marks peak lastinterglacial sea level, the net land-level change at Anegada in the past $120000 \mathrm{yr}$ has been close to nil.

\subsection{Microbial mats}

Microbial mats cover the floors of Anegada's salt ponds and extend onto adjoining playas as well (Jarecki et al., 2006). These modern mats play three main roles in the island's geologic records of Hurricane Earl (Sect. 4). First, fluffy mats on the perennial pond floors probably provided the main source for microbial detritus that the storm deposited widely at Anegada (Fig. S6-2, S6-3b-f, S6-4b, c, S6-5b, c). Second, firm mats of playas mark pre-hurricane surfaces beneath this microbial detritus (Fig. S6-3c) and beneath the deposits of sandy spillover fans beside the island's south shore (Fig. S5$2 \mathrm{~b}-\mathrm{d}, \mathrm{S} 5-3 \mathrm{~d}, \mathrm{e})$. Third, these recently buried mats serve as modern analogs for mats buried previously (Figs. S5-2b-f, S5-3b-f).

The building of a microbial mat has been called a "joint venture" among cyanobacteria, aerobic heterotrophic bacteria, sulphate-reducing bacteria, and sulphide oxidizers (van Gemerden, 1993). The initial colonists, cyanobacteria, generate oxygen from photosynthesis. Aerobic heterotrophs use this oxygen in producing sulfate from organic matter. Anaerobic heterotrophs reduce the sulphate to sulphide. Still other bacteria convert this sulphide back to sulphate.

Bacterial cells can secrete large organic molecules (Braissant et al., 2007). The secretions, known as extracellular polymeric substances (EPS), are important in microbiology and medicine as components of biofilms. The large organic molecules in EPS include sugars, lipids, and proteins (Decho, 2010). We assume that the microbial detritus from Hurricane Earl contains a mix of bacterial cells and EPS.

\subsection{Documented hurricanes}

The written history of hurricanes known to have passed near Anegada extends back to a storm that damaged nearby Tortola in 1713 (Pickering, 1983). Another hurricane damaged Tortola in 1819 (Schomburgk, 1832).

Hurricane Donna, in 1960, is among the largest hurricanes to have passed close to Anegada in the past $100 \mathrm{yr}$ or more (National Oceanic and Atmospheric Administration, 2012). To the east at Sint Maarten, Donna's maximum sustained wind was $110 \mathrm{kn}$ (about $55 \mathrm{~m} \mathrm{~s}^{-1}$ ) and the barometric pressure $952 \mathrm{mb}$ - category 3 on the Saffir-Simpson scale - and the storm was probably at category 3 or 4 until as it approached Florida (Dunn, 1961). The storm's eye has been mapped as passing $15 \mathrm{~km}$ south of Anegada (Dunn, 1961, p. 105) (Fig. S1-1b).

Hurricane Earl, following a track similar to Donna's, attained category 4 by the time it passed $30 \mathrm{~km}$ north of Anegada at 18:00 UTC (1 p.m.LT) on 30 August 2010 (Fig. S1-1c). It maintained winds of $115 \mathrm{kn}$ for the next $24 \mathrm{~h}$ (Cangialosi, 2011). Rainfall from the storm, gauged at Anegada, totaled nearly $11 \mathrm{~cm}$ according to unpublished data from the British Virgin Islands government.

Three other 20th-century storms were of category 4 when passing Anegada at distances greater than a few tens of kilometers (National Oceanic and Atmospheric Administration, 2012). On northwestward tracks, 1989 Hurricane Hugo passed $120 \mathrm{~km}$ to the south and 1995 Hurricane Luis $80 \mathrm{~km}$ to the north. 2008 Hurricane Omar, on an unusual northeastward track, passsed $80 \mathrm{~km}$ to Anegada's east.

Schomburgk (1832, p. 158) inferred that the 1819 hurricane closed an inlet on the island's north side, apparently north of Flamingo Pond in the area of Fig. S1-2b. Though an arm of Flamingo Pond extends in that direction, this arm appears to occupy a breach that cuts across beach ridges, and abundant beach ridges cast doubt on the persistence of an inlet in this area (Atwater et al., 2012b, p. 79).

\section{Findings}

\subsection{Storm-water limits}

Lines of plant fragments and other floatable debris mark high-water limits of Hurricane Earl on Anegada's shores and on the margins of its salt ponds as well.

These wrack lines are less than $2 \mathrm{~m}$ above sea level on the north shore near Windlass Bight (Fig. S3-1) and less than $1.5 \mathrm{~m}$ a.m.s.l. on the south shore west of The Settlement (Fig. S3-2). The heights were measured by means of a tripodmounted level in surveys with closure errors of $2 \mathrm{~cm}$ or less. The main uncertainty is the sea-level datum, which we estimated from tide levels on 5 and 7 February 2011. We assume that the tide levels are within $10 \mathrm{~cm}$ of mean sea level because the weather was fair and the Tortola tide ranges predicted for 
those days are just $12-16 \mathrm{~cm}$ (predictions from U.K. National Tidal and Sea Level Facility, NTSLF ${ }^{1}$ ).

The storm also engorged Anegada's eastern salt ponds, where we noted wrack lines but did not survey their heights (Fig. S3-4). We assume that paths through mangroves of the island's southeast shore enabled the eastern ponds to be flooded by the storm surge that was noted in The Settlement.

The storm surge during Hurricane Donna extended farther into The Settlement than did the surge during Hurricane Earl (Fig. S3-3). In The Settlement the Donna surge reached heights as much as $2.5 \mathrm{~m}$ a.s.l. (Atwater et al., 2012b, Fig. ESMF-1). Though we did not measure the heights reached by Earl in this area, these were doubtless lower because the Earl surge did not extend as far inland (Fig. S3-3f).

All these storm-water heights fall short of the elevations of $3 \mathrm{~m}$ or more that were likely required to have breached the beach ridges north of Red Pond and Bumber Well Pond (Atwater et al., 2012b, p. 67). Figure S6-1b shows, diagrammatically, the difference between peak water levels during Hurricane Earl and the threshold height for breaching the northern beach ridges.

\subsection{Spillover fans and their deposits}

Hurricane Earl thinly aggraded pre-existing fans that extend tens of meters inland from Anegada's south shore (Fig. S4-1-2). The fans are evident on oblique aerial photographs taken the morning of 31 August 2010-about $20 \mathrm{~h}$ after Earl's closest approach (The photographer was William Boyd McCleary, Governor of the British Virgin Islands). The fans persisted into February 2011, when we found sand and local mud as much as $10 \mathrm{~cm}$ thick atop leathery microbial mats that probably mark a pre-Earl fan surface. We call them spillover fans, rather than washover fans, to emphasize their limited landward extent.

The fans are lineated parallel to the probable inflow direction. Some of the light-colored streaks correspond to deposits of light-colored sand that cover pre-Earl microbial mats. Other light-colored streaks mark apparently eroded areas, rarely more than $1 \mathrm{~m}$ wide, where the pre-Earl mat is missing and light-colored pre-Earl sand is exposed (Fig. S41f, g, S4-2e). The apparent erosion extended about $10 \mathrm{~cm}$ deep at most.

Pits and trenches dug into two fans west of The Settlement exposed buried microbial mat layers that alternate with sand (Fig. S5-1-3). The sand units are typically stratified, commonly shelly (Fig. S5-3b), and locally cross-bedded (Fig. S5$3 \mathrm{~g}$ ). In one exposure of sand probably deposited during Hurricane Earl, a total thickness of $2 \mathrm{~cm}$ is divided into three parts by two partings of fine sand between shelly sand. This bedding did not appear graded when viewed in low-angle, rinsed cuts.

\footnotetext{
${ }^{1}$ http://www.ntslf.org/tides/predictions-other, accessed 2011 and later discontinued
}

With one possible exception, all the sand units probably postdate 1950 , for they overlie detrital leaves that contain surplus ${ }^{14} \mathrm{C}$ from atmospheric testing of nuclear weapons. The thickest of the sand units predate Hurricane Earl by stratigraphic superposition. Even if Hurricane Donna is represented by one of the sand units, the units are too numerous, especially in the east fan, to be accounted for by Donna and Earl alone. Additional storms, perhaps including 1989 Hugo and 1995 Luis, must have registered as bodies of spillover sand.

An eastern part of the east fan consists of lime mud, perhaps because it formed in the lee of mangroves. The sandy part of the fan, by contrast, is more open to the sea (Fig. S4$2 \mathrm{c})$. The mud may have been stirred up from the muddy sand of a shallow subtidal flat that extends hundreds of meters offshore from the south side of the island. Lime mud is the onshore overwash facies most widely deposited by Hurricane Donna in Florida (Ball et al., 1967).

\subsection{Blanket of microbial detritus}

The only widespread deposit of Hurricane Earl at Anegada is microbial detritus probably derived from mats of the island's salt ponds. This organic deposit blanketed the playas that fringe the salt ponds and extended into vegetated areas outside the flats. We assume that wind waves in the salt ponds suspended the material from fluffy mats that cover large fractions of the perennial pond floors.

As of February 2011 the microbial detritus was commonly $1-2 \mathrm{~cm}$ thick. Apparently structureless, it contrasted with laminated microbial mats beneath (Fig. S6-2d, c). On playas it had dried into chips and chunks (Fig. S6-2a, b, S6-3b-d, F, S6-4b, c, S6-5b, c). The drying had warped many of the chips into shapes curled (Fig. S6-3c) or knobby (Fig. S6-3d,f). Leaves that the microbial detritus used to cover had been exhumed by opening of cracks between the chips (Fig. S6-3d).

By March 2013 the microbial detritus was less evident on playas. Perhaps it had been broken down by rain or seasonal inundation, or its dried organic matter had partly decomposed. It was also being worked into the substrate by crabs. The potential for bioturbation by crabs is shown by counts of fiddler-crab burrows in 11 square-meter plots beside Red Pond in 1995. The counts peaked in April of that year at an average of 200 burrows per square meter (Jarecki, 2003, p. 115).

The knobby surfaces of the dried microbial detritus in Fig. S6-3d, f can be compared with similarly knobby surfaces described from microbial mats in Texas. In the Texas examples, the knobby surfaces were found in a vertical zone above most tides, and they were attributed to microbial coating of sand that had accumulated around grass roots (Bose and Chafetz, 2012). In the Anegada examples in Fig. S6-3d, the knobby surfaces formed in the absence of either sand or grass. 


\subsection{Comparisons with evidence for catastrophic overwash}

The microbial detritus contrasts with geologic evidence for catastrophic overwash in 1650-1800 and 1200-1450. The contrast is illustrated in Fig. S6, at locations keyed to the geologic sketch map in Fig. S6-1a. In the examples described below, field observations in the present tense refer to conditions in February 2011.

In the first example the microbial detritus coats the microbial mats of a salt pond that occupies a small breach near the island's north shore (Fig. S6-2). The breach suggests overwash that was erosive, and deposits beneath the mat horizon suggest that two overwash events had laid down sand at the site: first atop the sandy mud with marine-pond gastropods, second atop the microbial mat of a salt pond (Fig. S6-2c). Hurricane Earl, by contrast, caused no evident erosion at the breach and blanketed it with microbial detritus only.

In a second example, microbial detritus of Hurricane Earl coats the margins of the largest breach north of Red Pond (Fig. S6-3). Prior overwash that created or reoccupied this breach moved limestone boulders, an example of which is shown in Fig. S6-3e, g-j. The highest microbial detritus of Hurricane Earl failed to reach the level of the ground surface that surrounds this boulder.

On the north shore of Red Pond itself, microbial detritus of Hurricane Earl mantled a field of limestone cobbles and boulders (Fig. S6-4). The field extends southward from the limestone peninsula that is its probable source (Fig. S6-1a, S6-4c). The microbial detritus extends into a shoreline notch that was bare in 2008 (Fig. S6-4a, b).

On a playa west of Red Pond, the desiccated microbial detritus surrounds a well-preserved brain-coral head $1.5 \mathrm{~km}$ from the reef from which it was likely dislodged (Fig. S65). The head is one of three that provided initial evidence for the overwash of 1200-1450 (Fig. S6-5d). Another 15 coral heads from the island's northeast shore were dated early in 2012. Most of these also gave ages corresponding to 12001450 , and none are younger than that range (Weil Accardo et al., 2012).

The microbial detritus also coats playas underlain by a sheet of pink sand that marks catastrophic overwash in 16501800 or earlier (Fig. S6-1b). The sheet differs from the observed geologic effects of Hurricane Earl in consisting of sand grains and in extending an order of magnitude farther inland than do the sandy spillover fans that Earl aggraded on the island's south shore (Figs. S4, S5).

\section{Summary}

At Anegada, a low-lying island $120 \mathrm{~km}$ south of the Puerto Rico Trench, a category-4 hurricane had diminutive geologic effects compared with the erosional and depositional signs of southward overwash from the Atlantic Ocean in 1200-1450 and $1650-1800$. This conclusion is based on a field survey six months after 2010 Hurricane Earl, and on additional findings reported elsewhere about evidence for the prior, southward overwash. The survey was part of an effort to use Anegada's coastal geology as a guide to earthquake and tsunami potential along the Antilles Subduction Zone. This report calibrates that geology to the effects of 2010 Hurricane Earl.

Hurricane Earl caused widespread flooding at Anegada, chiefly by enlarging the island's interior salt ponds. The storm attained category 4 by the time it passed Anegada $30 \mathrm{~km}$ to the island's north on 30 August 2010. Combined effects of waves and storm surge left wrack lines on the island perimeter and around the salt ponds. Where measured by leveling in 2011, the perimeter lines were no more than $2 \mathrm{~m}$ a.m.s.l. on the north shore (at Windlass Bight) and about a half meter lower along the south shore (in and near The Settlement). These wrack lines were no more than a few tens of meters inland from the beach at Windlass Bight but as much as $300 \mathrm{~m}$ inland in The Settlement, where land slopes more gently into the sea. The flooding from the south nearly bisected the island by expanding Bumber Well Pond northward to beach ridges of Windlass Bight.

The storm's most widespread deposit consists of microbial detritus that is juxtaposed with erosional and depositional evidence for overwash that had greater geologic effects, and which dates to 1200-1450 (radiocarbon ages of brain-coral boulders) and 1650-1800 (radiocarbon ages on plant fragments). The detritus, probably derived from the fluffy microbial mats that coat the floors of salt ponds of the island interior, coated low areas around the ponds as a deposit up to $2 \mathrm{~cm}$ thick. The coating extended into areas that record prior overwash from the north: breaches near Windlass Bight, boulder fields south of those breaches, and playas underlain by a sand-and-shell sheet typically a few centimeters thick that was deposited sometime between 1650 and 1800. These juxtapositions show that at Anegada, the overwash events of 1200-1450 and 1650-1800 were more effective in eroding and depositing than was Hurricane Earl.

The sand-and-shell sheet of 1650-1800 also contrasts with spillover fans that Hurricane Earl aggraded on the island's south shore. The fans, made chiefly of sand, extend several tens of meters inland at most. Earl locally aggraded them with sand and mud as much as $10 \mathrm{~cm}$ thick. This deposit rests on a microbial-mat layer that the storm water may have eroded locally to depths of several centimeters. The sand contains cross bedding and is composed of fragments of shell and coral. It resembles underlying sand units that similarly overlie microbial mats. Most of these underlying units formed during the past $60 \mathrm{yr}$, as judged from radiocarbon ages on leaves that record the ${ }^{14} \mathrm{C}$ spike from atmospheric testing of nuclear weapons in the 1950s and early 1960s. Similarity to the deposits of Hurricane Earl suggests that these historical units also represent storms. The spillover fans differ from the 1650-1800 sand-and-shell sheet in direction (fans tapering toward the north, sheet derived largely from the north) and in inland extent (fans a few tens of meters, sheet as much as $1.5 \mathrm{~km}$ ). 
The breaching by prior overwash exceeded the onshore erosion by Hurricane Earl. The storm's overwash from the south may have cut into leathery mats on the spillover fans. If so, the erosion was limited to swaths centimeters deep and up to a meter across. Such erosion contrasts with the prehistoric breaching of beach ridges near the north shore. The north-side breaching in 1200-1450, 1650-1800, or both cut swaths meters deep and tens of meters wide through ridges that stood several meters above sea level. We found no evidence for such breaching at Anegada by Hurricane Earl.

Dating of Pleistocene coral clarifies the geologic setting of this late Holocene overwash. Deposits of Pleistocene reefs, sandy shoals, and beaches are widely exposed at Anegada. A detrital finger coral from these deposits, collected a few meters above modern sea level, yielded a uranium-series age of $121110 \pm 166 \mathrm{yr}$ that passed isotopic tests for reliability. If the coral accumulated close to the highest sea level during the last interglaciation, Anegada has undergone negligible net uplift since that time.

\section{Supplementary material related to this article is available online at http://www.adv-geosci.net/38/21/2014/ adgeo-38-21-2014-supplement.pdf.}

Acknowledgements. We thank residents of Anegada and for their hospitality. Garymar Rivera of the Department of Disaster Management provided the oblique airphotos taken the day after Hurricane Earl. Among the paper's authors, Brian Atwater prepared most of the manuscript and Zamara Fuentes drafted text on microbial mats. Michaela Spiske, Bruce Jaffe, and two anonymous referees improved the paper with manuscript reviews.

Edited by: J. Roger

\section{References}

Atwater, B. F., Musumi-Rokkaku, S., Satake, K., Tsuji, Y., Ueda, K., and Yamaguchi, D. K.: The orphan tsunami of 1700; Japanese clues to a parent earthquake in North America, U.S. Geological Survey Professional Paper 1707, 133 pp., available at: http:// pubs.usgs.gov/pp/pp1707/, last access: 15 February 2014, 2005.

Atwater, B. F., ten Brink, U. S., Feuillet, N., Fuentes Figueroa, Z., Halley, R. B., Tuttle, M. P., Wei, Y., and Weil Accardo, J.: Geologic evidence for a medieval tsunami with an eastern source along the Puerto Rico Trench, 2012 Fall Meeting, American Geophysical Union, San Francisco, USA, 3-7 December 2012, Abstract T41A-2566, 2012a.

Atwater, B. F., ten Brink, U. S., Buckley, M., Halley, R. B., Jaffe, B. E., López-Venegas, A. M., Reinhardt, E. G., Tuttle, M. P., Watt, S., and Wei, Y.: Geomorphic and stratigraphic evidence for an unusual tsunami or storm a few centuries ago at Anegada, British Virgin Islands, Nat. Hazards, 63, 51-84, doi:10.1007/s11069-010-9622-6, 2012b.
Atwater, B. F., Cisternas, M., Yulianto, E., Prendergast, A. L., Jankaew, K., Eipert, A. A., Fernando, W. I. S., Tejakusuma, I., Schiappacasse, L., and Sawai, Y.: The 1960 tsunami on beachridge plains near Maullín, Chile: landward descent, renewed breaches, aggraded fans, multiple predecessors, Andean Geol., 40, 393-418, doi:10.5027/andgeoV40n3-a01, 2013.

Ball, M. M., Shinn, E. A., and Stockman, K. W.: The geologic effects of Hurricane Donna in south Florida, J. Geol., 75, 583-597, 1967.

Barkan, R., ten Brink, U. S., and Lin, J.: Far field tsunami simulations of the 1755 Lisbon earthquake: Implications for tsunami hazard to the U.S. East Coast and the Caribbean, Mar. Geol., 264, 109-122, doi:10.1016/j.margeo.2008.10.010, 2009.

Beauducel, F. and Feuillet, N.: The great 1843 earthquake in the Lesser Antilles Arc, 2012 Fall Meeting, American Geophysical Union, San Francisco, CA, USA, 3-7 December, Abstract T41A2558, 2012.

Bose, S. and Chafetz, H. S.: Morphology and distribution of MISS; a comparison between modern siliciclastic and carbonate settings, in: Microbial mats in siliciclastic depositional systems through time, edited by: Noffke, N. and Chafetz, H., Society for Sedimentary Geology Special Publication 101, Tulsa, Oklahoma, USA, Society for Sedimentary Geology (SEPM), 3-14, 2012.

Braissant, O., Decho, A. W., Dupraz, C., Glunk, C., Przekop, K. M., and Visscher, P. T.: Exopolymeric substances of sulfate-reducing bacteria: Interactions with calcium at alkaline $\mathrm{pH}$ and implication for formation of carbonate minerals, Geobiology, 5, 401411, doi:10.1111/j.1472-4669.2007.00117.x, 2007.

Buckley, M., Wei, Y., Jaffe, B., and Watt, S.: Inverse modeling of velocities and inferred cause of overwash that emplaced inland fields of boulders at Anegada, British Virgin Islands, Nat. Hazards, 63, 133-149, doi:10.1007/s11069-011-9725-8, 2012.

Bush, D. M.: Impact of Hurricane Hugo on the rocky coast of Puerto Rico, J. Coastal Res., Special Issue No. 8, 49-67, 1991.

Buynevich, I. V. and Donnelly, J. P.: Geological signatures of barrier breaching and overwash, southern Massachusetts, USA, J. Coastal Res., Special Issue No. 39, 112-116, 2006.

Cangialosi, J. P.: Tropical cyclone report Hurricane Earl (AL072010) 25 August-4 September 2010, National Hurricane Center, 29 pp., available at: http://www.nhc.noaa.gov/pdf/ TCR-AL072010_Earl.pdf, last access: 15 February 2014, 2011.

Caribbean Disaster Mitigation Project: Atlas of probable storm effects in the Caribbean Sea, available at: http://www. oas.org/CDMP/document/reglstrm/Hurratlas7D.ppt, last access: 7 September 2012, 2002.

Cheng, H., Edwards, R. L., Hoff, J., Gallup, C. D., Richards, D. A., and Asmerom, Y.: The half-lives of uranium-234 and thorium-230, Chem. Geol., 169, 17-33, doi:10.1016/S00092541(99)00157-6, 2000.

Choowong, M., Murakoshi, N., Hisada, K., Charusiri, P., Daorerk, V., Charoentitirat, T., Chutakositkanon, V., Jankaew, K., and Kanjanapayont, P.: Erosion and deposition by the 2004 Indian Ocean tsunami in Phuket and Phang-nga Provinces, Thailand, J. Coastal Res., 23, 1270-1276, 2007.

Cox, R., Zentner, D. B., Kirchner, B. J., and Cook, M. S.: Boulder ridges on the Aran Islands (Ireland): recent movements caused by storm waves, not tsunamis, J. Geol., 120, 249-272, doi:10.1086/664787, 2012. 
Decho, A. W.: Overview of biopolymer-induced mineralization: What goes on in biofilms?, Ecol. Eng., 36, 137-144, doi:10.1016/j.ecoleng.2009.01.003, 2010.

Dolan, J. F. and Wald, D. J.: Comment on "The 1946 Hispaniola earthquake and the tectonics of the North AmericaCaribbean Plate Boundary Zone, northeastern Hispaniola" by R. M. Russo and A. Villasenor, J. Geophys. Res., 102, 785-792, doi:10.1029/96JB00648, 1997.

Dolan, J. F. and Wald, D. J.: The 1943-1953 north-central Caribbean earthquakes; active tectonic setting, seismic hazards, and implications for Caribbean-North America plate motions, in: Active strike-slip and collisional tectonics of the northern Caribbean plate boundary zone, edited by: Dolan, J. F. and Mann, P., Geological Society of America Special Publication 326, 143 169, 1998

Donnelly, J. P.: Evidence of past intense tropical cyclones from backbarrier salt pond sediments: a case study from Isla de Culebrita, Puerto Rico, USA, J. Coastal Res., SI 42, 201-210, 2005.

Donnelly, J. P. and Woodruff, J. D.: Intense hurricane activity over the past 5,000 yr controlled by El Nino and the West African monsoon, Nature, 447, 465-468, doi:10.1038/nature05834, 2007.

Dunn, G. E.: The hurricane season of 1960, Mon. Weather Rev., 89, 99-108, 1961.

Fagherazzi, S. and Du, X.: Tsunamigenic incisions produced by the December 2004 earthquake along the coasts of Thailand, Indonesia and Sri Lanka, Geomorphology, 99, 120-129, doi:10.1016/j.geomorph.2007.10.015, 2008.

Feuillet, N., Beauducel, F., and Tapponnier, P.: Tectonic context of moderate to large historical earthquakes in the Lesser Antilles and mechanical coupling with volcanoes, J. Geophys. Res., 116, B10308, doi:10.1029/2011JB008443, 2011.

Fritz, H. M., Blount, C. D., Albusaidi, F. B., and Al-Harthy, A. H. M.: Cyclone Gonu storm surge in Oman, Estuar. Coastal Shelf S., 86, 102-106, doi:10.1016/j.ecss.2009.10.019, 2010.

Geist, E. L. and Parsons, T.: Assessment of source probabilities for potential tsunamis affecting the U.S. Atlantic coast, Mar. Geol., 264, 98-108, doi:10.1016/j.margeo.2008.08.005, 2009.

Goff, J., McFadgen, B. G., and Chague-Goff, C.: Sedimentary differences between the 2002 Easter storm and the 15th-century Okoropunga tsunami, southeastern North Island, New Zealand, Mar. Geol., 204, 235-250, doi:10.1016/S0025-3227(03)003529, 2004.

Goff, J. R., Hicks, D. M., and Hurren, H.: Tsunami geomorphology in New Zealand : a new method for exploring the evidence of past tsunamis, NIWA Technical Report 128, 69 pp., http://webcat. niwa.co.nz/documents/0478232752.pdf, last access: 15 February 2014, 2007.

Harbitz, C. B., Glimsdal, S., Bazin, S., Zamora, N., Løvholt, F., Bungum, H., Smebye, H., Gauer, P., and Kjekstad, O., Tsunami hazard in the Caribbean: Regional exposure derived from credible worst case scenarios, Cont. Shelf Res., 38, 1-23, doi:10.1016/j.csr.2012.02.006, 2012.

Hippensteel, S. P.: Paleotempestology and the pursuit of the perfect paleostorm proxy, GSA Today, 20, 52-53, doi:10.1130/GSATG80GW.1, 2010.

Hoffman, G., Reicherter, K., Wiatr, T., Grützner, C., and Rausch, T.: Block and boulder accumulations along the coastline between
Fins and Sur (Sultanate of Oman): tsunamigenic remains?, Nat. Hazards, in press, doi:10.1007/s11069-012-0399-7, 2014.

Hua, Q. and Barbetti, M.: Review of tropospheric bomb (super 14) $\mathrm{C}$ data for carbon cycle modeling and age calibration purposes, Radiocarbon, 46, 1273-1298, 2004.

Jankaew, K., Atwater, B. F., Sawai, Y., Choowong, M., Charoentitirat, T., Martin, M. E., and Prendergast, A.: Medieval forewarning of the 2004 Indian Ocean tsunami in Thailand, Nature, 455, 1228-1231, doi:10.1038/nature07373, 2008.

Jarecki, L., Burton-MacLeod, S. M., and Garbary, D. J.: Ecology of algal mats from hypersaline ponds in the British Virgin Islands, Algae, 21, 235-243, 2006.

Jarecki, L. and Walkey, M.: Variable hydrology and salinity of salt ponds in the British Virgin Islands, Saline Systems, 2, 15 pp. doi:10.1186/1746-1448-2-2, 2006.

Jarecki, L. L.: Salt ponds of the British Virgin Islands: investigations in an unexplored ecosystem, Ph.D. thesis, University of Kent at Canterbury, Canterbury, UK, 2003.

Kilbourne, K. H., Quinn, T. M., Guilderson, T. P., Webb, R. S., and Taylor, F. W.: Decadal- to interannual-scale source water variations in the Caribbean Sea recorded by Puerto Rican coral radiocarbon, Clim. Dynam., 29, 51-62, doi:10.1007/s00382-0070224-2, 2007.

Kon'no, E., Iwai, J., Kitamura, N., Kotaka, T., Mii, H., Nakagawa, H., Onuki, Y., Shibata, T., and Takayanagi, Y.: Geological observations of the Sanriku coastal region damaged by the tsunami due to the Chile earthquake in 1960, Contributions from the Institute of Geology and Paleontology, Tohoku University, 52, 40 pp., 1961.

Kopp, R. E., Simons, F. J., Mitrovica, J. X., Maloof, A. C., and Oppenheimer, M.: Probabilistic assessment of sea level during the last interglacial stage: Nature, 462, 863-867, doi:10.1038/nature08686, 2009.

Kortekaas, S. and Dawson, A. G.: Distinguishing tsunami and storm deposits: An example from Martinhal, SW Portugal, Sediment Geol., 200, 208-221, doi:10.1016/j.sedgeo.2007.01.004, 2007.

Lario, J., Luque, L., Zazo, C., Goy, J. L., Spencer, C., Cabero, A., Bardaji, T., Borja, F., Dabrio, C. J., and Civis, J.: Tsunami vs. storm surge deposits: a review of the sedimentological and geomorphological records of extreme wave events (EWE) during the Holocene in the Gulf of Cadiz, Spain, Z. Geomorphol, 54, Suppl. 3, 301-316, 2010.

López, A. M., Stein, S., Dixon, T., Sella, G., Calais, E., Jansma, P., Weber, J., and LaFemina, P.: Is there a northern Lesser Antilles forearc block?, Geophys. Res. Lett., 33, L07313, doi:10.1029/2005GL025293, 2006.

López-Venegas, A. M., ten Brink, U. S., and Geist, E. L.: Submarine landslide as the source for the October 11, 1918 Mona Passage tsunami: Observations and modeling, Mar. Geol., 254, 35-46, doi:10.1016/j.margeo.2008.05.001, 2008.

Mann, M. E., Woodruff, J. D., Donnelly, J. P., and Zhang, Z.: Atlantic hurricanes and climate over the past $1,500 \mathrm{yr}$, Nature, 460 880-883, doi:10.1038/nature08219, 2009.

Mann, P. (Ed.): Active tectonics and seismic hazards of Puerto Rico, the Virgin Islands, and offshore areas, Geological Society of America Special Paper 385, 287 pp., 2005.

McCaffrey, R.: Global frequency of magnitude 9 earthquakes, Geology, 36, 263-266, doi:10.1130/G24402A.1, 2008. 
McCann, W. R.: On the earthquake hazards of Puerto Rico and the Virgin Islands, B. Seismol. Soc. Am., 75, 251-262, 1985.

Meltzner, A. J., Sieh, K., Chiang, H., Shen, C., Suwargadi, B. W., Natawidjaja, D. H., Philibosian, B. E., Briggs, R. W., and Galetzka, J.: Coral evidence for earthquake recurrence and an A.D. 1390-1455 cluster at the south end of the 2004 Aceh-Andaman rupture, J. Geophys. Res., 115, B10402, doi:10.1029/2010JB007499, 2010.

Mercado-Irizarry, A. and Liu, P. (Eds.): Caribbean tsunami hazard, Hackensack, N. J., World Scientific, 2006.

Monecke, K., Finger, W., Klarer, D., Kongko, W., McAdoo, B., Moore, A. L., and Sudrajat, S. U.: A 1,000-year sediment record of tsunami recurrence in northern Sumatra, Nature, 455, 12321234, doi:10.1038/nature07374, 2008.

Morton, R. A. and Sallenger Jr., A. H.: Morphological impacts of extreme storms on sandy beaches and barriers, J. Coast. Res., 19, 560-573, 2003.

Morton, R. A., Richmond, B. M., Jaffe, B. E., and Gelfenbaum, G.: Reconnaissance investigation of Caribbean extreme wave deposits; preliminary observations, interpretations, and research directions, U.S. Geological Survey Open-File Report 2006-1293, 45 pp., available at: http://pubs.usgs.gov/of/2006/1293/, last access: 15 February 2014, 2006.

Morton, R. A., Gelfenbaum, G., and Jaffe, B. E.: Physical criteria for distinguishing sandy tsunami and storm deposits using modern examples, Sediment. Geol., 200, 184-207, 2007.

Morton, R. A., Richmond, B. M., Jaffe, B. E., and Gelfenbaum, G.: Coarse-clast ridge complexes of the Caribbean: A preliminary basis for distinguishing tsunami and storm-wave origins, J. Sediment. Res., 78, 624-637, doi:10.2110/jsr.2008.068, 2008.

Muhs, D. R., Simmons, K. R., Schumann, R. R., and Halley, R. B.: Sea-level history of the past two interglacial periods: new evidence from U-series dating of reef corals from south Florida, Quaternary Sci. Rev., 30, 570-590, doi:10.1016/j.quascirev.2010.12.019, 2011.

Nanayama, F., Shigeno, K., Satake, K., Shimokawa, K., Koitabashi, S., Miyasaka, S., and Ishii, M.: Sedimentary differences between the 1993 Hokkaido-nansei-oki tsunami and the 1959 Miyakojima typhoon at Taisei, southwestern Hokkaido, northern Japan, Sediment. Geol., 135, 255-264, 2000.

National Oceanic and Atmospheric Administration: Historical hurricane tracks, available at: http://www.csc.noaa.gov/ hurricanes/\# (last access: 30 July 2012), 2012.

Otvos, E. G. and Carter, G. A.: Hurricane degradation-barrier development cycles, northeastern Gulf of Mexico: landform evolution and island chain history, J. Coastal Res., 24, 463-478, 2008.

Pickering, V. W.: Early history of the British Virgin Islands: from Columbus to emancipation, Falcon Publications International, New York, 1983.

Pilarczyk, J. and Reinhardt, E.: Homotrema rubrum (Lamarck) taphonomy as an overwash indicator in Marine Ponds on Anegada, British Virgin Islands, Nat. Hazards, 63, 85-100, doi:10.1007/s11069-010-9706-3, 2012.

Rajendran, C. P., Rajendran, K., Andrade, V., and Srinivasalu, S.: Ages and relative sizes of pre-2004 tsunamis in the Bay of Bengal inferred from geologic evidence in the Andaman and Nicobar Islands, J. Geophys. Res.-Sol. Ea., 118, 1345-1362, doi:10.1002/jgrb.50122, 2013.
Reimer, P. J. and Reimer, R.: CALIBomb radiocarbon calibration, available at: http://calib.qub.ac.uk/CALIBomb/ (last access: 29 July 2012), 2012.

Reimer, P. J., Baillie, M. G. L., Bard, E., Bayliss, A., Beck, J. W., Blackwell, P. G., Ramsey, C. B., Buck, C. E., Burr, G. S., Edwards, R. L., Friedrich, M., Grootes, P. M., Guilderson, T. P., Hajdas, I., Heaton, T. J., Hogg, A. G., Hughen, K. A., Kaiser, K. F., Kromer, B., McCormac, F. G., Manning, S. W., Reimer, R. W., Richards, D. A., Southon, J. R., Talamo, S., Turney, C. S. M., van der Plicht, J., and Weyhenmeye, C. E.: IntCal09 and Marine09 radiocarbon age calibration curves, 0-50,000 years cal BP, Radiocarbon, 51, 1111-1150, 2009.

Reinhardt, E., Pilarczyk, J., and Brown, A.: Probable tsunami origin for a shell and sand sheet from marine ponds on Anegada, British Virgin Islands, Nat. Hazards, 63, 101-117, doi:10.1007/s11069011-9730-y, 2012.

Richmond, B. M., Watt, S., Buckley, M., Jaffe, B. E., Gelfenbaum, G., and Morton, R. A.: Recent storm and tsunami coarse-clast deposit characteristics, southeast Hawai'i, Mar. Geol., 283, 7989, doi:10.1016/j.margeo.2010.08.001, 2011.

Rodríguez, R. W., Webb, R. M. T., and Bush, D. M.: Another look at the impact of Hurricane Hugo on the shelf and coastal resources of Puerto Rico, U.S.A., J. Coastal Res., 10, 278-296, 1994.

Sawai, Y., Fujii, Y., Fujiwara, O., Kamataki, T., Komatsubara, J., Okamura, Y., Satake, K., and Shishikura, M.: Marine incursions of the past 1500 years and evidence of tsunamis at Suijin-numa, a coastal lake facing the Japan Trench, The Holocene, 18, 517528, doi:10.1177/0959683608089206, 2008.

Scheffers, A. and Scheffers, S.: Documentation of the impact of Hurricane Ivan on the coastline of Bonaire (Netherlands Antilles), J. Coastal Res., 22, 1437-1450, doi:10.2112/05-0535.1, 2006.

Scheffers, A., Scheffers, S., and Kelletat, D.: Paleo-tsunami relics on the southern and central Antillean island arc, J. Coastal Res., 21, 263-273, doi:10.2112/03-0144.1, 2005.

Schomburgk, R. H.: Remarks on Anegada, Journal of the Royal Geographical Society of London, 2, 152-170, 1832.

Shah-hosseini, M., Morhange, C., Naderi Beni, A., Marriner, N., Lahijani, H., Hamzeh, M., and Sabatier, F.: Coastal boulders as evidence for high-energy waves on the Iranian coast of Makran, Mar. Geol., 290, 17-28, doi:10.1016/j.margeo.2011.10.003, 2011.

Spiske, M. and Halley, R. B.: A coral-rubble ridge as evidence for hurricane overwash, Anegada (British Virgin Islands), Adv. Geosci., 38, 9-20, doi:10.5194/adgeo-38-9-2014, 2014.

Spiske, M. and Jaffe, B. E.: Sedimentology and hydrodynamic implications of a coarse-grained hurricane sequence in a carbonate reef setting, Geology, 37, 839-842, doi:10.1130/G30173A.1, 2009.

Spiske, M., Böröcz, Z., and Bahlburg, H.: The role of porosity in discriminating between tsunami and hurricane emplacement of boulders - A case study from the Lesser Antilles, southern Caribbean, Earth Planet. Sc. Lett., 268, 384-396, doi:10.1016/j.eps1.2008.01.030, 2008.

Stuiver, M. and Reimer, P. J.: A computer program for radiocarbon age calibration, Radiocarbon, 28, 1022-1030, 1986.

Switzer, A. D. and Burston, J. M.: Competing mechanisms for boulder deposition on the southeast Australian coast, Geomorphology, 114, 42-54, doi:10.1016/j.geomorph.2009.02.009, 2010. 
Switzer, A. D. and Jones, B. G.: Large-scale washover sedimentation in a freshwater lagoon from the southeast Australian coast; sea-level change, tsunami or exceptionally large storm?, The Holocene, 18, 787-803, doi:10.1177/0959683608089214, 2008.

Tanaka, H., Xuan Tinh, N., Umeda, M., Hirao, R., Pradjoko, E., Mano, A., and Udo, K.: Coastal and estuarine morphology changes induced by the 2011 great east Japan earthquake tsunami, Coast. Eng. J., 54, 1250010, doi:10.1142/S0578563412500106, 2012.

ten Brink, U., Dillon, W., Frankel, A., Mueller, C., and Rodriguez, R. W.: Seismic and tsunami hazard in Puerto Rico and the Virgin Islands, U.S. Geological Survey Open-file Report 99-353, available at: http://pubs.usgs.gov/of/1999/of99-353/, last access: 15 February 2014, 1999.

ten Brink, U. S. and López-Venegas, A. M.: Plate interaction in the NE Caribbean subduction zone from continuous GPS observations, Geophys. Res. Lett., 39, L10304, doi:10.1029/2012GL051485, 2012.

ten Brink, U. S., Danforth, W. W., Polloni, C. F., Andrews, B., Llanes, P., Smith, S., Parker, E., and Uozumi, T.: New seafloor map of the Puerto Rico trench helps assess earthquake and tsunami hazards, Eos T. Am. Geophys. Un., 85, 349-354, 2004.

ten Brink, U. S., Bakun, W. H., and Flores, C. H.: Historical perspective on seismic hazard to Hispaniola and the northeast Caribbean region, J. Geophys. Res., 116, B12318, doi:10.1029/2011JB008497, 2011.

Thompson, W. G., Curran, H. A., Wilson, M. A., and White, B.: Sea-level oscillations during the last interglacial highstand recorded by Bahamas corals RID H-2407-2011, Nat. Geosci., 4, 684-687, doi:10.1038/NGEO1253, 2011.

Toscano, M., Macintyre, I., and Lundberg, J.: Last interglacial reef limestones, northeastern St. Croix, US Virgin Islands - evidence of tectonic tilting and subsidence since MIS 5.5, Coral Reefs, 31, 27-38, doi:10.1007/s00338-011-0822-7, 2012.
Tuttle, M. P., Ruffman, A., Anderson, T., and Jeter, H.: Distinguishing tsunami from storm deposits in Eastern North America; the 1929 Grand Banks tsunami versus the 1991 Halloween storm, Seismol. Res. Lett., 75, 117-131, 2004.

van Gemerden, H.: Microbial mats; a joint venture, Mar. Geol., 113, 3-25, 1993.

Watt, S., Buckley, M., and Jaffe, B.: Inland fields of dispersed cobbles and boulders as evidence for a tsunami on Anegada, British Virgin Islands, Nat. Hazards, 63, 119-131, doi:10.1007/s11069011-9848-y, 2012.

Wei, Y., ten Brink, U., Atwater, B. F., Tuttle, M. P., Halley, R., Feuillet, N., Weil Accardo, J., and Fuentes, Z.: Near-field tsunami inferred from numerical modeling of medieval overwash at Anegada, British Virgin Islands, Fall Meeting, AGU, San Francisco, CA, USA, 3-7 December 2012, Abstract OS32A-05, 2012.

Weil Accardo, J., Feuillet, N., Halley, R. B., Atwater, B. F., Ten Brink, U. S., Deschamps, P., Tuttle, M. P., Wei, Y., and Fuentes Figueroa, Z.: Age of overwash and rate of relative sea-level rise inferred from detrital heads and microatolls of medieval corals at Anegada, British Virgin Islands: American Geophysical Union 2012 Fall Meeting abstract T41A-2562, 2012.

Woodruff, J. D., Donnelly, J. P., Emanuel, K., and Lane, P.: Assessing sedimentary records of paleohurricane activity using modeled hurricane climatology, Geochem. Geophy. Geosy., 9, Q09V10, doi:10.1029/2008GC002043, 2008a.

Woodruff, J. D., Donnelly, J. P., Mohrig, D., and Geyer, W. R.: Reconstructing relative flooding intensities responsible for hurricane-induced deposits from Laguna Playa Grande, Vieques, Puerto Rico, Geology, 36, 391-394, doi:10.1130/G24731A.1, 2008b. 